\title{
Holy Verses in the EFL/ESL Classroom as Literary Text: Teaching Reading
}

\author{
Md. Arif Khan Pathan* \\ Assistant Professor (English), Department of Languages, Bangladesh Agricultural University, Mymensingh, \\ Bangladesh \\ *Corresponding Authors: Md. Arif Khan Pathan, Assistant Professor (English), Department of \\ Languages, Bangladesh Agricultural University, Mymensingh, Bangladesh
}

\begin{abstract}
There are many advantages of using literary texts in the EFL/ESL classroom. The EFL/ESL teachers use literary texts in the classroom for many purposes and it's been a very popular practice now-a days. The use of a religious scripture as a literary text in the EFL/ESL classroom, on the other hand, is also getting popular todaythatoffers some extra benefits along with the benefits a literary text usually provides. Different translated versions of the world's major religious scriptures like Al-Quran, Bible, etc. are now being used in the classrooms to teach different languages around the world. The purpose of the present study was to find out the suitability and appropriateness of the classroom application of the holy verses from AlQuran in the EFL classroom environment to teach reading. The study also investigated the impacts of using holy verses in the EFL classroom through taking into account students' interest, motivation, and participation in the classroom. By using some suitable verses of Al-Quran in English and developing some readingactivitieson the selected verses, the study taught the reading skill to the tertiary level EFL students, and found the whole approach very much positive, interesting, and motivational to the students.
\end{abstract}

Keywords: EFL/ESL Classroom; Holy Verses; Literary Text; Teaching Reading

\section{INTRODUCTION}

The use of literary texts in the EFL/ESL classroom is, now-a-days, a very common and popular issue. The EFL/ESL teachers use literary texts in the classroom for various reasons and purposes. For example, literary texts serve as authentic materials that not only give the students the opportunity to deal with the authentic language use, but also help teachers to construct authentic language activities. They also encourage and motivate students to participate in the classroom activities by providing interesting content. In addition, literary texts offer varieties of language use, different types of language patterns and structures, and multiple layers of meaning along with a wide range of vocabulary. Unlike the texts of the course-books that use referential language- a language that 'communicates on only one level, usually in terms of information being sought or given' (McRae, 1991) ${ }^{[1]}$, literary texts use representational language that occupies the learners' imagination, and develops their ability to think in the target language which is considered to be a very important skill for language learning. The importance of using literary texts in the classroom can also be perceived in the following quote: "By constructing with the literary text a reality different from that of texts of information, students are given access to a world of attitudes, and values, collective imaginings and historical frames of reference that constitute the memory of a people or speech community" (Kramsch, 1993 quoted by Gray, 2005) ${ }^{[2]}$.

However, let's talk about the significance of using holy verses in the EFL/ESL classroom as literary text. We notice a significant number of religions in the world. Among them almost all the major religions have at least one religious scripture each. The followers of a particular religion believe its scripture to be a revelation from their God, and consider the scripture to be the finest piece of literature in its original language. Although different religious scriptures were revealed in different languages, most of them have later been translated into many other languages especially in English. So, we can use the English translation of any religious scripture according to the need. Even if the simple English translation of any scripture is used in the classroom, the students will still have certain type of feeling in their minds that they are reading the best text of the world that has come from the 
God. This type of sacred feeling will definitely provoke students' interests and inspirations in learning. The teachers, on the other hand, can largely be benefited by the holy verses not only in constructing authentic, meaningful, and interesting language activities, but also in teaching the students ethics and moral values. Linguistically, a religious scripture also offers an extensive array of language use both referential and representational, varied language patterns and structures, and a comprehensive collection of vocabulary that show a great diversity in meaning. Moreover, all scriptures are exceptionally rich in beautiful and thought-provoking content that canundeniablyboost students' imagination and creativity. One more important thing to mention here that in all the educational institutions where religious studies are compulsory especially in preliminary and intermediate level; if English is taught through religious scripture, it will surely reduce the load from the shoulder of the students and make them feel stress-free. On the other hand, where religious studies are neither taught as a compulsory nor an optional subject, if English is taught there through religious scripture, it will act as a two-in-one package.

\section{LITERATURE REVIEW}

During the period of the Grammar Translation Method, the use of literary texts in the ESL/EFL classroom was very regular as translating literary texts from the second/foreign language to the students' native language was one of the recurrent activities carried out in the classroom. But after the replacement of the method by some other methods like the Direct Method and the Audio-lingual Method that emphasized grammatical forms, structures, and vocabulary; literary texts lost their value in the classroom. Even in the later methods such as the Community Language Learning, Suggestopedia, the Silent Way, Total Physical Response, and the Natural Approach; literary texts held no place at all in the ESL/EFL classroom. However, after the appearance of the Communicative Language Teaching, literary texts found their way back into the classroom and received more attention of the teachers.

Numerous studies have shown the advantages and ways of using literary texts in the ESL/EFL classroomto develop students' language skills. For example, Collie and Slater (1987) ${ }^{[3]}$ explained why a language teacher should use literary texts with classes by stating four reasons: valuable authentic material, cultural enrichment, language enrichment and personal involvement. They also explicated what sort of literature is suitable for use with language learners, and how best the teacher and students can work with it. Hamdoun and Hussain (2010) ${ }^{[4]}$ examined the need and importance of literary texts for a comprehensive attainment of higher levels of language skills and found that the literary texts can play a vital role in developing language skills among the non-native learners of English and helping them to use language for communicative purposes in the real world. Hismanoglu (2005) ${ }^{[5]}$ nicely expounded why, what, and how to use literary texts to teach both basic language skills (i.e. listening, speaking, reading, and writing) and language areas (i.e. vocabulary, grammar, and pronunciation). $\mathrm{He}$ also elucidated the benefits of using different genres of literature to language teaching. Ritlyova $(2014)^{[6]}$ illustrated how literary texts can be creatively used in language teaching and also suggested some useful activities that can help teachers while working with literary texts. Skela (2014) ${ }^{[7]}$ explored the proven benefits of using literary texts in EFL and also examined the presence of literary texts in a selection of past and current EFL course books. Chen (2014) ${ }^{[8]}$ proved that literature for children can be effectively used to acquire English as a foreign language in students of all ages and provided some suggestions for practical applications of language acquisition and learning principles in five categories of activities using English language literature. Silva $(2001)^{[9]}$ described the reasons of applying literature to ESL teaching and presented short stories and song lyrics as suitable approaches to teach all the four skills of language for teaching young/adult learners from the intermediate level onwards. Ozkan and Tongur (2014) ${ }^{[10]}$ studied that the use of literary texts in the reading classes raises students' motivation and language awareness, develops students' interpretative abilities, sparks curiosity, helps students become more productive and creative, stimulates students' language acquisition, and helps students to be more actively involved intellectually and emotionally in learning English. Lao and Krashen's (2000) ${ }^{[11]}$ study revealed that EFL students can make superior gains on measures of vocabulary and reading rate through reading literary texts compared to students enrolled in a traditional reading class. Salma $(2007)^{[12]}$ and Phat $(2013)^{[13]}$ investigated how to effectively teach and develop speaking skills in a literature class as well as how to develop the students' inspirations in studying literature. Elhabiri $(2012)^{[14]}$ inspected how to exploit literary texts to develop students' writing skills and observed that the use of literary texts helped students progress their writing abilities significantly by making them familiar with new vocabularies, different linguistic 
forms and functions of sentences, as well as with different ways of organizing, developing, and connecting ideas. McKay (1982) $)^{[15]}$, Brumfit and Carter (1986) ${ }^{[16]}$, Lazar (1993) $)^{[17]}$, Llach (2007) ${ }^{[18]}$, Pardede $(2011)^{[19]}$, Yeasmin et al. (2011) ${ }^{[20]}$, Irene $(2015)^{[21]}$, and many others also explored why and how to use literary texts in the ESL/EFL classroom to develop students' language skills.

However, Almenoar $(2013,2014)^{[22][23][24][25][26][27]}$ made conclusive findings on the suitability of using Al-Quran as a literary text in the EFL classroom. All her studies nicely demonstrate how perfectly the verses of Al-Quran can be used in the classroom. She used the verses of Al-Quran in the classroom not only to teach vocabulary and grammar, but also to build up students' higher order thinking skills, to develop their communicative competence, as well as to increase their motivation and performance in the classroom. She also developed a number of lesson plans and suggested appropriate pedagogical approaches whereby teachers are able to see the classroom application of the verses of Al-Quran in English.

\section{RESEARCH PURPOSE}

The purpose of the present study is to find out the suitability and appropriateness of the classroom application of the holy verses from Al-Quran in the EFL classroom environment to teach reading. The study will also investigate the positive and negative impacts of using holy verses in the EFL classroom through taking into account students' interest, motivation, and participation in the classroom.

\section{RESEARCH METHODOLOGY}

\subsection{Selection of English Translation of Al-Quran}

Usually, it is very difficult to translate a literary text from its original language to any other language retaining its literary value, linguistic beauty, intensity of meaning, etc. Translating a religious scripture is no exception. Moreover, the sense that the sacred language used in the scripture is of the God only that must be translated with ultimate accuracy and grave mood, makes it most difficult to translate. Therefore, to maintain the supreme accuracy and solemn mood, the words and the language structures and patterns the translator use deviate largely from the common language. However, there are some translators who have tried their best to simplify the language in their translations to make them better understood by the common people. Here the most simplified English translation of AlQuran selected by the researcher for the purpose of the study wasthe Sahih International translation of Al-Quran.

\subsection{Selection of Verses to be used to Teach Reading Skill}

After selecting the most simplified and suitable English translation of Al-Quran, the researcher's next task was to select some appropriate verses from Al-Quran that would be used to teach reading skill. A special attention was paid in this task since the primary purpose of Al-Quran is not to teach any language to its reader. It has its own purpose which is not basically the concern of this study. However, after scrutinizing some chapters of Al-Quran, the researcher found verses 65-82 of chapter18 (Appendix-1) most appropriate to teach reading skill.

\subsection{Developing Reading Activities}

After selecting the most appropriate verses, the researcher focused on developing some reading activities to be carried out in the classroom to teach reading skill. The activities were divided into two categories: pre-reading activities \& post-reading activities (Appendix-2).

\subsection{Applying in the Classroom}

After developing the reading activities, the researcher then carried them out in the English language classes of Bangladesh Agricultural University. There were total 269 participants who belonged to the different faculties (Faculty of Veterinary Science, Faculty of Agricultural Economics \& Rural Sociology, and Faculty of Fisheries) of the university. All of them were $1^{\text {st }}$ year- $1^{\text {st }}$ Semester B. Sc. (Hons.) students. They are basically taught English as a compulsory subject. Most of them were Muslims and a few were Hindu.

\subsection{Conducting the Survey}

Finally, the researcher conducted a survey with a questionnaire (Appendix-3) to find out the positive and negative impacts of using holy verses in the EFL classroom. The questionnaire was distributed to 
each student right after the class, and the students were only required to put tick marks on appropriate options. The questionnaire employs a Likert-type scale through which the students expressed their views and conveyed their judgments, and the researcher, in return, obtained a clear picture of the effectiveness of using holy verses in the EFL classroom.

\section{RESULTS AND DISCUSSION}

\begin{tabular}{|c|c|c|c|c|c|c|}
\hline & & $\begin{array}{l}\text { Strongly } \\
\text { Agree }\end{array}$ & Agree & $\begin{array}{l}\text { Neither Agree } \\
\text { Nor Disagree }\end{array}$ & Disagree & $\begin{array}{l}\text { Strongly } \\
\text { Disagree }\end{array}$ \\
\hline 1. & The class was enjoyable. & $\begin{array}{l}178 \\
(66.17 \%)\end{array}$ & $\begin{array}{l}89 \\
(33.09 \%)\end{array}$ & $\begin{array}{l}1 \\
(0.37 \%)\end{array}$ & $\begin{array}{l}1 \\
(0.37 \%)\end{array}$ & $\begin{array}{l}0 \\
(0 \%)\end{array}$ \\
\hline 2. & The text was easy to understand. & $\begin{array}{l}74 \\
(27.51 \%)\end{array}$ & $\begin{array}{l}157 \\
(58.36 \%)\end{array}$ & $\begin{array}{l}26 \\
(9.67 \%)\end{array}$ & $\begin{array}{l}12 \\
(4.46 \%)\end{array}$ & $\begin{array}{l}0 \\
(0 \%)\end{array}$ \\
\hline 3. & The text was interesting. & $\begin{array}{l}183 \\
(68.03 \%)\end{array}$ & $\begin{array}{l}81 \\
(30.11 \%)\end{array}$ & $\begin{array}{l}4 \\
(1.49 \%)\end{array}$ & $\begin{array}{l}1 \\
(0.37 \%)\end{array}$ & $\begin{array}{l}0 \\
(0 \%)\end{array}$ \\
\hline 4. & $\begin{array}{l}\text { The content of the text was thought- } \\
\text { provoking. }\end{array}$ & $\begin{array}{l}136 \\
(50.56 \%)\end{array}$ & $\begin{array}{l}114 \\
(42.38 \%)\end{array}$ & $\begin{array}{l}14 \\
(5.20 \%)\end{array}$ & $\begin{array}{l}5 \\
(1.86 \%)\end{array}$ & $\begin{array}{l}0 \\
(0 \%)\end{array}$ \\
\hline 5. & $\begin{array}{l}\text { The content of the text was } \\
\text { appropriate to the class. }\end{array}$ & $\begin{array}{l}143 \\
(53.16 \%)\end{array}$ & $\begin{array}{l}105 \\
(39.03 \%)\end{array}$ & $\begin{array}{l}16 \\
(5.95 \%)\end{array}$ & $\begin{array}{l}4 \\
(1.49 \%)\end{array}$ & $\begin{array}{l}1 \\
(0.37 \%)\end{array}$ \\
\hline 6. & $\begin{array}{l}\text { The text was helpful to learn moral } \\
\text { values and ethics. }\end{array}$ & $\begin{array}{l}224 \\
(83.27 \%)\end{array}$ & $\begin{array}{l}40 \\
(14.87 \%)\end{array}$ & $\begin{array}{l}5 \\
(1.86 \%)\end{array}$ & $\begin{array}{l}0 \\
(0 \%)\end{array}$ & $\begin{array}{l}0 \\
(0 \%)\end{array}$ \\
\hline 7. & $\begin{array}{l}\text { This type of text can be used in } \\
\text { language teaching. }\end{array}$ & $\begin{array}{l}124 \\
(46.10 \%)\end{array}$ & $\begin{array}{l}124 \\
(46.10 \%)\end{array}$ & $\begin{array}{l}17 \\
(6.32 \%)\end{array}$ & $\begin{array}{l}2 \\
(0.74 \%)\end{array}$ & $\begin{array}{l}2 \\
(0.74 \%)\end{array}$ \\
\hline 8. & $\begin{array}{l}\text { This type of text can be used in } \\
\text { hetero-religious class. }\end{array}$ & $\begin{array}{l}98 \\
(36.43 \%)\end{array}$ & $\begin{array}{l}139 \\
(51.67 \%)\end{array}$ & $\begin{array}{l}28 \\
(10.41 \%)\end{array}$ & $\begin{array}{l}3 \\
(1.12 \%)\end{array}$ & $\begin{array}{l}1 \\
(0.37 \%)\end{array}$ \\
\hline 9. & The activities were engaging. & $\begin{array}{l}98 \\
(36.43 \%)\end{array}$ & $\begin{array}{l}160 \\
(59.48 \%)\end{array}$ & $\begin{array}{l}10 \\
(3.72 \%)\end{array}$ & $\begin{array}{l}1 \\
(0.37 \%)\end{array}$ & $\begin{array}{l}0 \\
(0 \%) \\
\end{array}$ \\
\hline 10. & The activities suit the text well. & $\begin{array}{l}134 \\
(49.81 \%)\end{array}$ & $\begin{array}{l}122 \\
(45.35 \%)\end{array}$ & $\begin{array}{l}13 \\
(4.83 \%)\end{array}$ & $\begin{array}{l}0 \\
(0 \%)\end{array}$ & $\begin{array}{l}0 \\
(0 \%)\end{array}$ \\
\hline
\end{tabular}

From the results of the survey, it is found that almost all the participants have enjoyed the class. Although only a small number of participants have found the text a bit difficult to understand, majority are on the view that the text is easy. Nearly all the participants have also marked that the text is interesting and thought-provoking. According to them, the content of the text is appropriate to the class and the text is helpful to learn moral values and ethics. Most of the students are also on the view that this type of text can be used in language teaching and also in hetero-religious classrooms. Finally, almost everyone has found the activities engaging and fitting to the text.

\section{CONCLUSION}

The use of a religious scripture as a literary text in the EFL/ESL classroom is not a novel concept. Different translated versions of Bible are being used in the classrooms to teach different languages. Al-Quran as a literary text has also found its place in the EFL/ESL classroom. The present study tried to exploit Al-Quran as a literary text in the EFL classroom to teach reading skills. The study also examined the effects of using Al-Quran in the EFL/ESL classroom through taking into account students' interest, motivation, and participation in the classroom, and found the whole approach very much positive, interesting, and motivational to the students.

\section{REFERENCES}

[1] McRae, J. (1991). Literature with a Small 'l'. London: Macmillan.

[2] Gray, R. (2005). Using translated first language literature in the second language classroom. The Internet TESL Journal, 11. Retrieved from http://iteslj.org/Techniques/Gray-TranslatedL1Literatue.html

[3] Collie, J., \& Slater, S. (1987). Literature in the Language Classroom: A Resource Book of Ideas and Activities. Cambridge: CUP.

[4] Hamdoun, Q. H., \& Hussain, S. S. (2010). Teaching Language through Literature: A diagnostic study on the. English Studies in India, 18. Retrieved from https://www.pdffiller.com/43915421--TeachingLanguage-through-Literaturedoc-repository-ksu-edu

[5] Hismanoglu, M. (2005). Teaching English through literature. Journal of Language and Linguistic Studies, 1(1), 53-56. Retrieved from http://www.jlls.org/index.php/jlls/article/viewFile/6/7 
[6] Ritlyova, A. (2014). Creative Use of Literature in Language Teaching. Tvorivost $v$ skole- skola tvorivosti 2 Online Conferencia 29-30.10.2014, 94-102. Retrieved from https://www.pulib.sk/web/kniznica/elpub/ dokument/Germuskova2/subor/Ritlyova.pdf

[7] Skela, J. (2014). The Quest for Literature in EFL Textbooks- A Quest for Camelot? English Language Overseas Perspectives and Enquiries, 11(1), 113-136.

[8] Chen, M. L. (2014). Teaching English as a Foreign Language through Literature. Theory and Practice in Language Studies, 4(2), 232-236.

[9] Silva, R. B. (2001). Using Literary Texts in the ESL classroom. R. Ci. Humanas, 1(2), 171-178.

[10] Ozkan, A., \& Tongur, A. N. (2014). Use of literature in reading comprehension classes by ELT teacher. The Internation Journal of Social Sciences, 25, 66-72.

[11]Lao, C. Y., \& Krashen, S. (2000). The impact of popular literature studyon literacy development in EFL: More evidence for the power of reading. System, 28, 261-270.

[12] Salma, A. (2007). Use of literature in developing learner's speaking skills in Bangladeshi EFL contexts. Doctoral Dissertation. Retrieved from http://eprints.nottingham.ac.uk/14033/1/446394.pdf

[13]Phat, C. H. (2013). The implementation of literature in teaching speaking for advanced students. 3rd International Conference on Foreign Language Learning and Teaching, (pp. 671-688). Thailand. Retrieved from http://www.litu.tu.ac.th/journal/FLLTCP/Proceeding/671.pdf

[14]Elhabiri, H. (2012). Teaching the writing skills through literary texts. Doctoral dissertation. Retrieved from http://dspace.univ-tlemcen.dz/bitstream/112/3593/1/habiri-houria.pdf

[15] McKay, S. (1982). Literature in the ESL classroom. TESOL Quarterly, 16(4), 529-536.

[16] Brumfit, C. J., \& Carter, R. A. (1986). Literature and Language Teaching. Oxford: Oxford University Press.

[17]Lazar, G. (1993). Literature and Language Teaching: A Guide for Teachers and Trainers. Cambridge: Cambridge University Press.

[18]Llach, P. A. (2007). Teaching language through literature: The Waste Land in the ESL classroom. Odisea, 8, 7-17.

[19] Pardede, P. (2011). Using short stories to teach language skills. Journal of English Teaching, 1(1), 14-27.

[20] Yeasmin, N., Azad, A. K., \& Ferdoush, J. (2011). Teaching language through literature: Designing appropriate classroom activities. ASA University Review, 5(2), 283-297.

[21] Irene, K. V. (2015). The use of literature in the language classroom: Methods and aims. International Journal of Information and Education Technology, 5(1), 74-79.

[22] Almenoar, L. (2013). Learning through music using Quranic verses in English. IOSR Journal of Humanities and Social Science, 16(3), 66-76.

[23] Almenoar, L. (2014). Canned questions using Quranic verses in English. IOSR Journal of Research \& Method in Education, 4(4), 29-36.

[24] Almenoar, L. (2014). Four corners vocabulary using Quranic verses in English. International Journal on Studies in English Language and Literature, 2(7), 5-16.

[25] Almenoar, L. (2014). Hots using Quranic verses in English. International Journal of Managerial Studies and Research, 2(6), 29-41.

[26] Almenoar, L. (2014). Productive pyramid presentation using Quranic verses in English. Asian Journal of Social Sciences and Humanities, 3(1), 189-202.

[27] Almenoar, L. (2014). Snowballing using Quranic verses in English. International Journal of Humanities Social Sciences and Education, 1(7), 52-65.

\section{Appendix-1}

\section{Al-Quran 18:65-82}

65/1. And they found a servant from among Our servants [i.e., al-Khidhr] to whom We had given mercy from Us and had taught him from Us a [certain] knowledge.

66/2. Moses said to him, "May I follow you on [the condition] that you teach me from what you have been taught of sound judgment?"

$67 / 3$. He said, "Indeed, with me you will never be able to have patience.

68/4. And how can you have patience for what you do not encompass in knowledge?"

69/5. [Moses] said, "You will find me, if Allah wills, patient, and I will not disobey you in [any] order."

70/6. He said, "Then if you follow me, do not ask me about anything until I make to you about it mention [i.e., explanation]." 
71/7. So they set out, until when they had embarked on the ship, he [i.e., al-Khidhr] tore it open. [Moses] said, "Have you torn it open to drown its people? You have certainly done a grave thing." 72/8. [Al-Khidhr] said, "Did I not say that with me you would never be able to have patience?"

73/9. [Moses] said, "Do not blame me for what I forgot and do not cover me in my matter with difficulty."

74/10. So they set out, until when they met a boy, he [i.e., al-Khidhr] killed him. [Moses] said, "Have you killed a pure soul for other than [having killed] a soul? You have certainly done a deplorable thing."

75/11. [Al-Khidhr] said, "Did I not tell you that with me you would never be able to have patience?"

76/12. [Moses] said, "If I should ask you about anything after this, then do not keep me as a companion. You have obtained from me an excuse."

77/13. So they set out, until when they came to the people of a town, they asked its people for food, but they refused to offer them hospitality. And they found therein a wall about to collapse, so he [i.e., al-Khidhr] restored it. [Moses] said, "If you wished, you could have taken for it a payment."

78/14. [Al-Khidhr] said, "This is parting between me and you. I will inform you of the interpretation of that about which you could not have patience.

79/15. As for the ship, it belonged to poor people working at sea. So I intended to cause defect in it as there was after them a king who seized every [good] ship by force.

80/16. And as for the boy, his parents were believers, and we feared that he would overburden them by transgression and disbelief.

81/17. So we intended that their Lord should substitute for them one better than him in purity and nearer to mercy.

$82 / 18$. And as for the wall, it belonged to two orphan boys in the city, and there was beneath it a treasure for them, and their father had been righteous. So your Lord intended that they reach maturity and extract their treasure, as a mercy from your Lord. And I did it not of my own accord. That is the interpretation of that about which you could not have patience."

\section{Appendix-2}

\section{Pre-reading activities}

\section{Activity-1 (General discussion for growing interest)}

a) Have you heard the word 'patience'? How will you define it?

b) Can you recall a time or event when you kept incredible patience or you could not keep patience at all?

c) How long will you keep patience if you see someone making a hole in a boat that belongs to a poor man or killing an innocent boy in front of you?

\section{Activity-2 (Identifying meaning for better understanding)}

a) And how can you have patience for what you do not encompass in knowledge?

b) "Have you torn it open to drown its people? You have certainly done a grave thing."

c) "Have you killed a pure soul for other than [having killed] a soul? You have certainly done a deplorable thing."

d) And as for the boy, his parents were believers, and we feared that he would overburden them by transgression and disbelief.

e) And I did it not of my own accord.

\section{Post-reading activities}

Activity-1 (Identifying true and false statement)

a) Al-Khidhr was the servant of Moses.

b) Moses intentionally asked and charged Al-Khidhr for tearing the ship open.

c) Al-Khidhr killed an innocent boy.

d) Al-Khidhr restored the wall for getting food.

e) Moses could not keep patience because he did not have sufficient knowledge.

\section{Activity-2 (Answering questions)}

a) What did Moses want to learn from Al-Khidhr?

b) On what condition did Al-Khidhr permit Moses to follow him?

c) Why did Al-Khidhr tear the ship open?

d) Why did not Al-Khidhr take any payment for restoring the wall? 


\begin{tabular}{l}
\hline e) How did the two orphan boys get the treasure beneath the wall? \\
Activity-3 (Sharing opinions) \\
a) What is your opinion about Al-Khidhr? Was he a good or bad person? Support your opinion with \\
information from the text. \\
b) What would you do if you were there instead of Moses? Would you do the same thing as Moses did \\
or something different?
\end{tabular}

\section{Appendix-3}

\begin{tabular}{|l|l|l|l|l|l|l|}
\hline & & $\begin{array}{l}\text { Strongly } \\
\text { Agree }\end{array}$ & Agree & $\begin{array}{l}\text { Neither Agree } \\
\text { Nor Disagree }\end{array}$ & Disagree & $\begin{array}{l}\text { Strongly } \\
\text { Disagree }\end{array}$ \\
\hline 1. & The class was enjoyable. & & & & & \\
\hline 2. & The text was easy to understand. & & & & & \\
\hline 3. & The text was interesting. & & & & & \\
\hline 4. & $\begin{array}{l}\text { The content of the text was thought- } \\
\text { provoking. }\end{array}$ & & & & & \\
\hline 5. & $\begin{array}{l}\text { The content of the text was } \\
\text { appropriate to the class. }\end{array}$ & & & & & \\
\hline 6. & $\begin{array}{l}\text { The text was helpful to learn moral } \\
\text { values and ethics. }\end{array}$ & & & & & \\
\hline 7. & $\begin{array}{l}\text { This type of text can be used in } \\
\text { language teaching. }\end{array}$ & & & & & \\
\hline 8. & $\begin{array}{l}\text { This type of text can be used in } \\
\text { hetero-religious class. }\end{array}$ & & & & & \\
\hline 9. & The activities were engaging. & & & & & \\
\hline 10. & The activities suit the text well. & & & & & \\
\hline
\end{tabular}

\section{AUTHOR'S BIOGRAPHY}

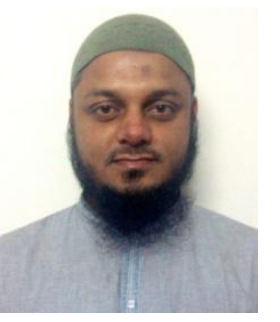

Mr. Md. Arif Khan Pathan, is an assistant professor of English in the Department of Languages at Bangladesh Agricultural University, Mymensingh, Bangladesh. His major research interests include pronunciation, oral communication, and EFL/ESL teaching methodology.

Citation: Md. Arif Khan Pathan. "Holy Verses in the EFL/ESL Classroom as Literary Text: Teaching Reading" International Journal on Studies in English Language and Literature (IJSELL), vol 8, no. 5, 2020, pp. 01-07. doi: http://dx.doi.org/10.20431/2347-3134.0805001.

Copyright: (C) 2020 Authors. This is an open-access article distributed under the terms of the Creative Commons Attribution License, which permits unrestricted use, distribution, and reproduction in any medium, provided the original author and source are credited. 